Volume 1 No. 1, Agustus 2018

E-ISSN 2622-9056

UniversitasBanten Jaya

\title{
IMPROVING ESP STUDENT'S WRITING SKILL BY USING WRITING ESSAY MODEL
}

\author{
Ina Rohiyatussakinah \\ Fadilla Oktaviana \\ Universitas Banten Jaya \\ Serang, Indonesia \\ inarohiyatussakinah@unbaja.ac.id \\ fadilla@unbaja.ac.id
}

\begin{abstract}
Writing as productive skill is closed with learner in university. They should do lots of writing. English for Academic Purposes programme such as English for Environmental Engineering can be involved in keeping issue logs which are kind of project work. This research investigated of using essay in teaching English as media to improve students' writing skill. The writer conducted a classroom action research as a method in this research. Writer used Essay as media that was implemented in Environmental engineering class at Banten Jaya University. The class consisted of 25 students. This research was conducted in two cycles. Before doing the treatment, writer gave students pre-test. The mean score of students' pre test was 65 . It indicates that their writing was low. After that, the writer implemented the treatment and gave students post-test. The result of test in cycle one shows that there was improvement, the score was 75. It indicates that there was an improvement from pre-test and post-test one. But, it is still not maximal. Thus, the writer conducted the next cycle (cycle two) in order to reach the target that the students could reach score 80 . The result of test in cycle two (post-test two) shows that mean score of students writing was 85. Thus, the using Essay model in teaching writing is excellent to improve students' writing skill. They was able to gathering ideas, organising the ideas and make essay paragraph with varieties topic that related on their field.
\end{abstract}

Keywords: Improving, writing skill, essay model 


\section{INTRODUCTION}

Writing is the necessary for students ESP Class on University Level. Studentscan practice to gathering and organizing the ideas. The lecturer and the English learners should be able to write English and also produce the essay as their expression of the ideas. Furthermore, they should good on writing skill.

productive skill in written mode, it is more complicated than it seems at first, and often seems to be the hardest of the skill, even for native speakers of a language, since it involves not just a graphic representation of speech, but the development and presentation of thought in a structured way. There are various ways how to define writing. Most writing systems are based on speech; writing is just a visual representation of speech (writing is symbol of symbol) (Seken.2017, P.12)

Writing is one way of providing variety in classroom procedure. It provides a learner with physical evidence of his achievement and he can measure his improvement. It helps to consolidate their grasp of vocabulary and structure, and complement the other language skills.

Four basic skills on writing are grammar, vocabulary, organization and language feature. It can be faced for ESP class on their writing skill. English for specific academic purpose especially for engineering class is too hard and confuse material. To implement the four skill on writing they should remember special vocabularies based on their field for example waste, logging, pollution, reservation, climate change, etc. they need some treatment to improve their writing skill, therefore they need essay model to create and improve their productive skill.

Essay model treatment here based on their field (environmental engineering) consists of introduction, body and conclusion. In their essay paragraph student still confuse on organizing the idea, structure, vocabulary and grammar. They create essay writing with specific term on environment engineering such as waste, pollution, sanitation; illegal logging etc. it is the basic matter for their essay writing product.

Based on the explanation, program in term of ESP (English for Specific Purposes), is an important and dynamic area of specialization within the field of English language teaching and learning especially for English on University level. Since the purpose of ESP is to help learners to be equipped with the specific domains of language knowledge and skills, and to apply these skills appropriately in the specific discipline, profession, or workplace, the special language needs of the specific context and subject at the collage.

Problem are often occurred in the university level on English learning make students confuse to produce academic writing. So, the writer assumes that by using Essay model can improve their writing skill.

Writing in ESP classroom is productive skill of language learning. It involves gathering ideas, and other important elements at writing, such as grammar, vocabulary, etc. They should be taught in any language learning to make the learners able to use the target language written communication.

Writing is the skill that the learners will be communicating by giving and gathering 
ideas on written text. It is an important part of student interaction in the classroom to express their ideas especially on ESP class. Thus, the lecturer has a responsibility to prepare the learners as much as possible to be able to write English in the learning.

Writing is one of productive skill in English. Writing is a tool of human communication that creates language and through the inscription or recording of sign, symbols, characters and letter.

As mode communication, writing should be reviewed as representation a dialogue between the writers and their readers. This view of writing as a social process, (Hyland, 2003). Writing has often been considered as secondary to oral communication, i.e writing as a means of representation and substituting spoken ideas into written ones (harmer,2007) even in second language learning, writing used to be viewed as a mere "support system "to learning language components : grammar and vocabulary (Harmer, 2007)

Well argue that writing has the ability to "put agreements, laws, and commandments on record. There are variety of teach tools or methods out there for teaching writing that can make the process easier. There so many kinds of method and teaching technique for writing in order to make students more interesting. There are some technique focused ways to help students learn grammar, essay-writing, and the most important thing is the role of writing skill for the learner.

How to write an essay? It is common question for every English learner. Commonly essay has the basic part or structure there are introduction, body and conclusion. Each part has different content for example:

a. Introduction : dramatic opener or hook (transitional sentence and thesis statement)

b. Body: topic sentences (detailed and example) concluding transitional sentences. The body of your essay can be three ore more paragraph long

c. Conclusion : summary statement (restart your thesis)

Every essay has beginning, a middle and an end. In a five paragraph essay, the first paragraph is called introduction, the next three paragraphs consist of the body of the essay. The fifth and final paragraph is the conclusion.

There are three important things to consider as you write your essay:

a. Subject: throughout your educational career, lecturer will be giving you writing assignment. They want to see if you understand material covered in the class. They want to know your opinion in particular topic, and they want to determine if you can express ideas clearly. They will be occasion when you will want to write an essay in other situation

b. Audience: Many times your audience will be your lecturer. Sometimes even though your lecturer is primary reader of your essay. He or she will ask you write to a different audience. Other time your audience will be your peers, parents, employers, newspaper editor, or the community. 
Exactly before you writing an essay your audience should determine how you will write and what you will say in your essay. Before you start writing you should do the following; (a) understand the audience's interests and perspectives (b) evaluate your topic in relation to your audience (c) adapt your topic, example, and language so that they appropriate for your audience

c. Purpose ; the purpose of your essay will determine what types of essay you will write. Each type has certain uses and style.

Basic types of writing essay model:

1. Narrative : recall an event or series of event

2. Expository : explain, clarifies, or illustrates

3. Response to literature : show that you understand a literary work (poem, book, story) and can make judgment about the text will evidence to support it

4. Summaries : write summaries that contains the main ideas of reading selection and the most significant details

5. Information reports : a report where you do research, and you cite fact from different source (book, magazine, or online article)

For this research the writer used information report essay model because it relevant with their field. Before they write the essay they found from online article and cite the fact into essay paragraph.

\section{METHOD}

The writer used a qualitative which is a part of a broad movement that has been going on in education generally for some time. It is related to the ideas of reflective practice and the lecturer as writer. Action research involves taking a self-reflective, critical, and systematic approach to exploring your own context (“Burn, 2010, p. 2)

This research usedClassroom Action Research (CAR). The purpose of classroom action research is to provide lecturer with a method to solve daily problem in the class, in order to improve their writing English skill by essay model.

The writer used the Kemmis and McTaggarts model. According to Kemmis and Mc Taggart action divided into two cycles and conducted in four procedures, those are: Planning, Action, Observation, and Reflection. Writer uses the this research design because it is suitable with the objective research to improve the effectiveness of teaching methods and to improve the quality of learning teaching practices Arikunto (2013:132).

Technique of the Data Collecting

The data will be collected by using qualitative and quantitative technique.

a) Qualitative technique Observation

Observation has taken in teaching and learning process.

b) Quantitative technique 
For quantitative technique, the writer gave the test, in every cycle to measure the improvement of students' writing skill. The writer count the result of the test from the student's and analyze the score to know the improvement of the students in writing skill.

\section{Instrument of the Data Collecting}

The writer used the test as instrument of the data collecting; the objective of the test was used to identify the students' achievement in writing.

This research, writer used pre-test and post-test. Pre-test to know ESP students 'writing skill before treatment. Post-test to measure Essay paragraph model to improve their English writing skill.

\section{Qualitative data analysis}

To analyze the data, the writer used matric descriptive of Miles and Huberman (1994: 10) the data divided in data reduction, data display, data conclusion/ drawing verification.

\section{a. Data reduction}

First, the data had to be organized and somehow meaningfully reduced Milles and Huberman (1994: 21) data reduction refers to the process of selecting, and transforming the field notes from writer.

\section{b. Data display}

All display is designed to assemble and organized information in an immediately accessible. Therefore, the analyst can see what happening and either justified conclusion.

\section{c. Conclusion / drawing verification} The third step to analyze the data is conclusion / drawing verification. The process of verification involves testing the meaning that was emerging from the data for their likelihood and for whether or not they can be confirmed.

2. Quantitative data analysis technique The writer use some formula in quantitative to find out the improving students pronunciation by using audio visual media to find out the mean score of pre-test and post-test, the writer calculated the average by using formula as follow:

$$
\overline{\mathbf{X}}_{=} \frac{\sum \mathbf{x}}{\mathbf{n}}
$$

Where:

$$
\begin{array}{ll}
\overline{\mathbf{x}} & : \text { Mean score } \\
\Sigma \mathbf{x} & : \text { The sum off all score } \\
\mathrm{n} \quad \text { : The total number of subject } & \\
& \text { Hatch and Farhady }(1982: 55)
\end{array}
$$

Percentage of students' frequency

The writer calculated the percentage of students' frequency by using formula as follow:

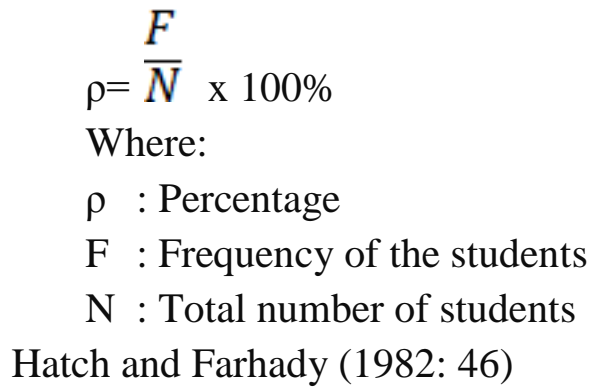

\section{DISCUSSION}

In this part, the writer provides the result of the research. There was comparison among pre-test, post-test in cycle one, and post-test in cycle two in 
order to know whether the treatment effective or not.

\section{Table I}

The Result of Test in Each Cycle

$\begin{array}{cccc}\text { Category } & \begin{array}{c}\text { Pre- } \\ \text { test }\end{array} & \begin{array}{c}\text { Post- } \\ \text { test } \mathbf{1}\end{array} & \begin{array}{c}\text { Post- } \\ \text { test } \\ \mathbf{2}\end{array} \\ \text { MIN } & 63 & 70 & 75 \\ \text { MAX } & 75 & 85 & 95 \\ \text { MEAN } & 65 & 75 & 85\end{array}$

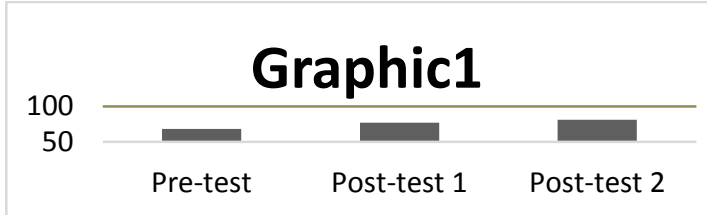

\section{Graphic I}

The Comparison of the Students' writing skill Result in Each Cycle

The table and graphic showed that there was significant enhancement of students' writing skill. Fromthe pre-test, the mean score of students, from the result of students writing, the mean score of students' pre-test was 65. It indicates that students still low in writing skill. However, after writer gave treatment to them, writer proposed the posttest one. The result of post-test shows the enhancement of students' scores. The mean score was 75 then, the writer provided cycle two in order to reach the target of this research. After conducting the post-test two, the mean score was 85 . It indicates that the using can improve students writing skill.

From the result, it can be concluded that this research was successful because $80 \%$ students can reach the target. in other word, can be used as media in teaching writing.

\section{CONCLUSION}

After the study had been completely conducted and the data needed had been gained and processed. Referring to the data and the result of the research In addition, the using of essay model in teaching learning writing by the model above also helps the technique to be going well. The synchronizing between the technique and the media is really helpful writing practice in the classroom.

In this part, the writer will draw some conclusions about the research and also would give some suggestions as the contribution to support the teaching learning process.

1. The process of implementing essay model to improve students writing most the students are interested in learning English. It seems that they feel more relax instead of treatment with the theory. Their motivation in learning English increases and expect that this kind of program will be regularly and continuously. Having the learning situation which could take the learners into students' world, it would certainly facilitate the lecturer to handle the class and to transfer the knowledge easier to the students, so that the target of study be maximally achieved.

2. The result of students' writing skill through essay model, the students have improved writing skill. The students carefully and correctly The writer concluded that an increase in the students' achievement had happened after students got some treatments; it 
was proven by the comparison between the result of the pre-test in the first cycle and until of the post-test in the second cycle in which the post-test result is higher $(85 \%)$ than pre-test is $(70 \%)$ and it is about (15\%).

Based on the results of the research, some suggestions are proposed to the following groups.Writer suggests for the lecturer to put essay model in teaching learning process in order to make the students to be easier in writing and avoid from misunderstanding on their written report. In addition, the lecturer should produce well written text, at least not to close to the native language of the lecturer in order to avoid misconception. Then, the lecturer should give another way in teaching writing, so the teaching learning process will not be conventional. For the students, the writer suggests them to be more active in teaching learning process.

Writer suggests to other writer who will investigate the similar research but in another subject to the other writer also can be implementing the similar model but in different skills. They should pay more attention in time allocation, and make a good lesson plan. Therefore, the writer will be better. Writer also suggest to the other writer to practice essay model to improve their writing skill.

\section{REFERENCES}

Anne, Burn. 2010. Doing Action Research in English Language Teaching: A guide for Practitioner. New York: Routledge.

Arikunto, Suharsimi. 2013. ProsedurPenelitian. Jakarta: RinekaCipta.

Harmer, Jeremy. 2007. How to teach writing. Cambridge: Cambridge University Press

Hyland K,. 2003. Second language Writing. Cambridge: Cambridge University Press

.Seken, ketut.2017.Introduction to Linguistic.Second Edition. Bogor: GrafindoPress.

Well, H.G. 1922. A short history of the world. 